Smith, later identified by R. Folker and C. S. Houston); Yellow bellied Flycatcher (Empidonax flaviventris) banded at Beaver Creek on August 29 and September 5 (C. S. Houston), killed at TV tower on September 3; Traill's Flycatcher (Empidonax traillii) banded on September 12 and 19 at Beaver Creek (C. S. Houston) ; Raven (Corvus corax) on September 26 (Saskatoon, P. Andres), October 3 (Highway 60), October 17 (Saskatoon, J. F. Roy) and November 7 (Goose Lake); a flock of six Eastern Bluebirds (Sialia sialis) was studied on October 3 ten miles east of Donovan; Philadelphia Vireo (Vireo philadelphicus)_-TV tower kills on August 31 (G. Fox) and September 4, banded at Beaver Creek on September 12 (C. S. Houston); Blackburnian Warbler (Dendroica fusca) on May 23 near Borden Bridge (M. A. Gollop) ; Canada Warbler (Wilsonia canadensis) banded on August 20 and September 1 in Saskatoon (C. S. Houston); an adult male Western Tanager (Piranga ludoviciana) found dead beneath a window on Elliott Street on June 8 (W. J. Maher).

\title{
GREATER PRAIRIE CHICKEN IN SOUTHERN ALBERTA
}

\author{
by Bryan R. Shantz, Calgary
}

The last sight records of Greater Prairie Chicken, Tympanuchus cupido pinnatus (Brewster), reported in Alberta were in 1939 and 1940 (A. L. Rand, 1948. Birds of Southern Alberta. Nat. Mus. Canada Bull. 111; G. J. Mitchell, 1959. Alberta's Upland Game Bird Resources Queen's Printer, Edmonton). The last specimen record for the province was in 1929.

On September 14, 1965 eight Greater Prairie Chicken were seen about eight miles west of Coutts, Alberta, southeast of Lethbridge. The birds were seen about two miles north of the International Boundary. They were observed by myself and Mr. R. J. Bunnage of Glenwood, Alberta; while we were doing a range survey for the Alberta Department of Lands and Forests on the grazing lease of the Milk River Cooperative Grazing Association. The area is open rolling prairie, dominated by Idaho fescue; however, cultivated land occurs only two miles to the south, in Montana. The elevation of the site is 4,200 feet.
The birds flushed from a fence line at the approach of our truck. They were at first thought to be Sharptailed Grouse, but closer observation showed that they were not. The two distinguishing characteristics noted at the time were the heavily barred breast and the squarish tail. These are in contrast to the lightly spotted breast and the pointed tail of the Sharp-tailed Grouse. The birds flew only 200 feet, where they landed as a group and stood watching us. The birds were clearly observed with the aid of seven power binoculars for five or ten minutes and were still there when we drove away.

In view of the 25-year gap in the sight records for Alberta, it is unlikely that this flock is a remnant of the former resident population. Although it is possible that Greater Prairie Chicken may still breed in Saskatchewan (Blue Jay, 21:14, $1963)$, the species has also been recorded there only infrequently during the last 25 years (Blue Jay, 19:76$77,1961)$. 


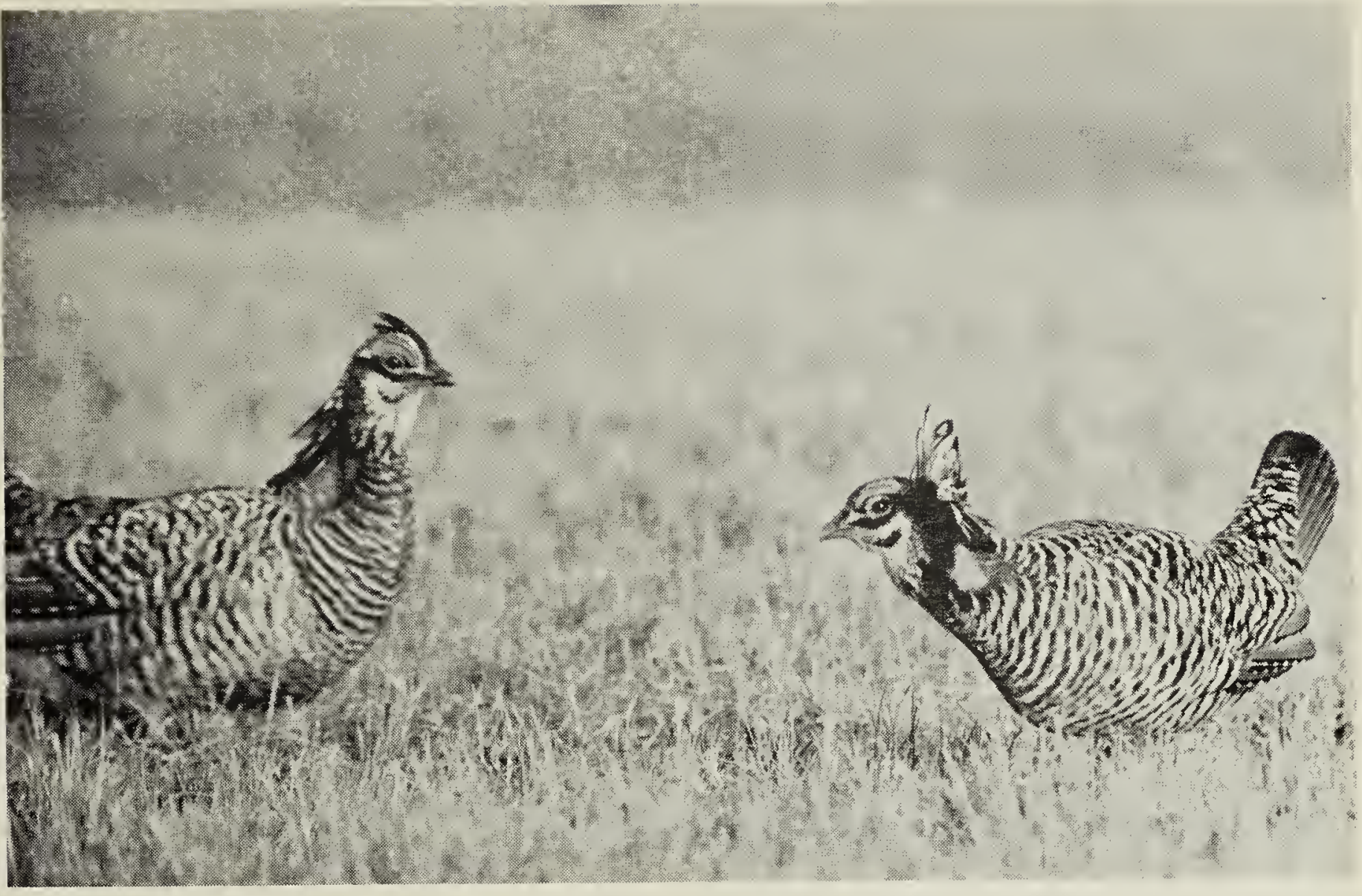

Photo by Miss Kay Hodges, Calgary Greater Prairie Chicken, males sparring on Wisconsin booming grounds

\section{RECORD OF WOOD DUCK AT LITTLE QUILL LAKE}

by Jack C. Shaver, Regina

On August 9, 1965, while I was assisting two students who were banding waterfowl this past summer for the Game Division of the Saskatchewan Department of Natural Resources, we captured an adult male Wood Duck. The trap was located on the south shore of Little Quill Lake (northeast of Watrous). Editor's Note: Another interesting record of the Wood Duck for the summer of 1965 appears in the report of observations in the Saskatoon area, p. 77.

\section{FATAL ENTANGLEMENT OF COMMON TERN}

by C. Stuart Houston, Saskatoon

Bird bander Walter P. Nickell's report on fatal entanglements of Herring Gulls and Common Terns in the Auk, 81:555-556, October, 1964, has prompted me to submit the accompanying photograph. This shows a
Common Tern which died as a result of becoming accidentally entangled in a plant. This adult Common Tern was found in a nesting colony on an island in Redberry Lake, July 28, 1963, hanging by its neck from the fork of a prickly lettuce plant, Lactuca scariola. When we found it, the tern had been dead for several days.

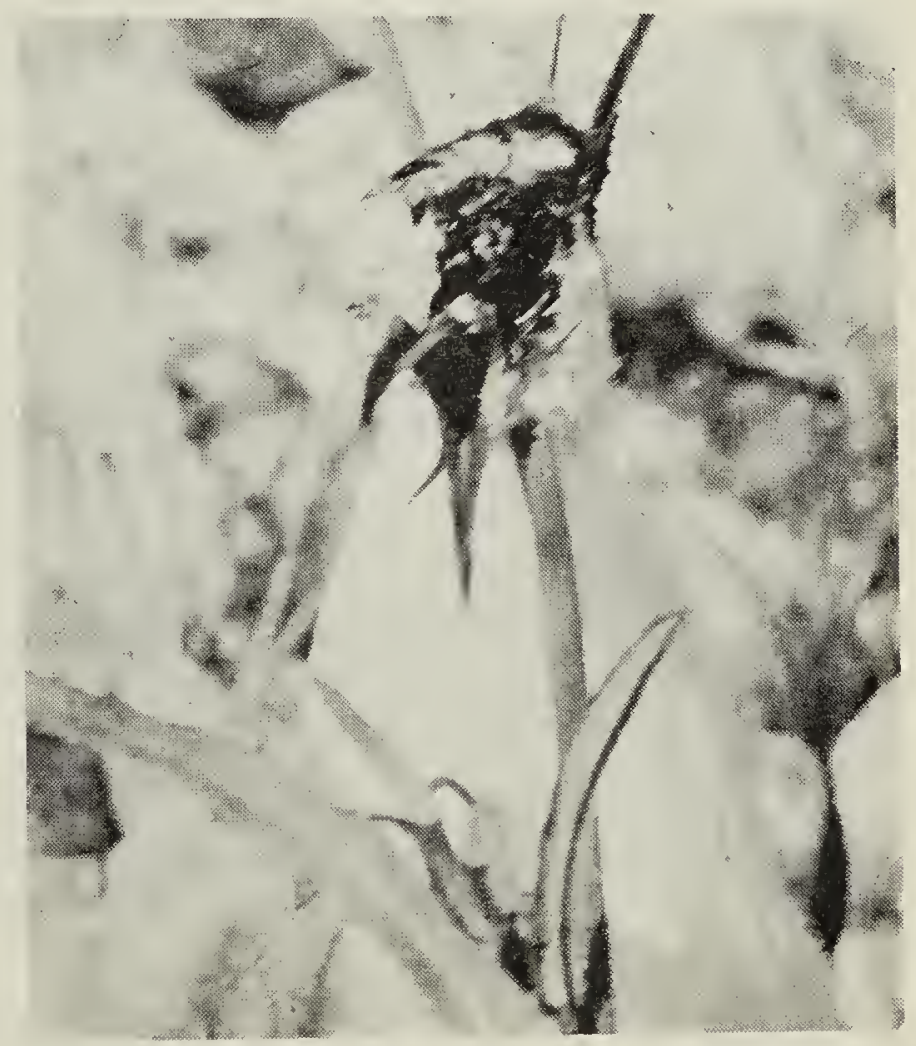

